\title{
Environmental Investments in New Technologies
}

\author{
Jarosław Korpysa \\ Dr hab., Department of Microeconomics, Institute of Economics, Faculty of \\ Economic and Management, University of Szczecin
}

\section{Theoretical Approach}

Globalization processes, changing consumer expectations and increasing competition force businesses to vigorously search for new environmental technologies that will minimize pollutant emissions as well as save natural resources. In this sense, environmental technologies relate to all forms of creating and implementing production or services processes striving to acquire higher effectiveness and responsibility of a company in the field of using natural resources (Bocken et al. 2014). Therefore, actions for new environmental technologies leading to full exploitation of the environmental potential of particular solutions constitute an essential element of reinforcement of environmental protection policy for companies. The goal of these actions is to exploit the potential of a new technology in order to execute environmental challenges efficiently, while at the same time improving the competitiveness of the entities functioning on the market (Beltrán-Esteve \& Picazo-Tadeo 2015). At this point it is important to bear in mind that the new environmental technologies industry includes mainly the sectors dealing with climate friendly technologies, controlling air pollution, waste water management and recycling. Currently, these sectors, whose annual value is EUR 600 billion, already comprise one third of the world's market (Bossle et al. 2016).

\section{How to cite this book chapter:}

Korpysa, J. 2019. Environmental Investments in New Technologies. In: Gąsior, A. (ed.)

Pro-ecological Restructuring of Companies: Case Studies, Pp. 135-144. London:

Ubiquity Press. DOI: https://doi.org/10.5334/bbk.k. License: CC-BY 4.0 
The actions that are connected with new technologies for environmental protection include both pro-ecological investments (also called investment projects) and as various types of organizational and technical procedures reducing the negative impacts of entrepreneur's actions on the environment. Therefore, these investments may be defined as expenditure on creating new, enlarging the existing or restoration of used objects of tangible assets, whose goal is to conserve water, air, land, biodiversity and landscape as well as protection from noise and radiation. Some authors also include, in the category of pro-ecological investments, both investments whose goal is environmental conservation and those whose aim is to produce goods and services used in environmental protection, i.e. the investments in eco-industries (Wang 2015).

In the literature, it is assumed that the investments connected with environmental conservation might be divided according to the character of an investment. In this regard, so-called end-of-pipe or integrated investments may be distinguished. The specificity of the investments of the first kind is reduction or neutralization of the pollutions created in the production process. These investments do not limit the amount of produced pollution but limit their negative consequences (Zhang 2013). The second type of pro-ecological undertakings of new technologies are integrated investments, which, being part of the production process, reduce the amount of produced pollution at the source and change its quality to more environmentally friendly. As a result, the production becomes cleaner.

Some researchers identify investing in the creation of new technologies with creating eco-innovations. At this point it is important to bear in mind that the concept of eco-innovation exists in different forms in the subject literature. Therefore, eco-innovations lead to integrated solutions aimed at decreasing resources and energy expenditures, while at the same time improving the quality of products and services. Another definition is proposed by Triguero, Moreno-Mondéjar and Davia (2013), who define eco-innovation as changes in technology, organizational structure and managing the company which minimize the negative impact on the environment. However, according to Ghisetti, Marzucchi, Montresor (2015), eco-innovation is innovation integrating ecological features of a product and technology. Some researchers identify ecoinnovation with each innovation that leads to the achievement of sustainable development by means of limiting the negative impact of production activities on the environment, increasing nature's resilience to environmental pressures or ensuring higher efficiency and responsibility in the field of use of natural resources (Beltrán-Esteve \& Picazo-Tadeo 2015). Others claim that ecoinnovations are new or significantly improved solutions (products, processes, methods of organization and marketing) whose goal is different than current management of natural resources, in compliance with the rules of sustainable development (sustainable development innovations) (Bossle et al. 2016).

In spite of the diversity of definitions, it should be stated that ecoinnovations strive to develop new products and processes that not only 
provide values to the consumer and business, but also minimize the negative effects of the influence that market entities have on the environment. From such a perspective, the main feature of ecological innovation is creating new environmental technologies that contribute to reducing the environmental burden.

In the context of these reflections, it is worth remembering that creating new technologies for environmental purposes is connected with the concept of Best Available Technology (BAT). The concept of BAT refers to a set of technical facilities, methods of operation and organizational solutions - the best from the perspective of preventing, reduction or neutralization of pollutions, which became applicable on an industrial scale in the case of at least one manufacturer, without entailing excessive costs for adapting to the conditions and needs of another manufacturer. It means that the cost should be proportional to the accomplished effect (Loyon et al. 2016). Therefore, the concept of BAT is connected with utilizing low-waste technologies, using less dangerous substances, developing recovery and recycling of substances created and used in production processes, as well as wastes, improvements to their methods of operating that have been successfully tested on an industrial scale, technological progress and knowledge development (Wen et al. 2016).

In the USA and EU countries, the concept of BAT has been extended by a concept requiring the entities to use "best available technology not entailing excessive costs" (BATNEEC). BATNEEC, together with Council Directive 96/61/WE on integrated IPPC environmental permits, means increased pressure on entrepreneurs in connection with implementation of modern technical and technological solutions based on innovations and scientific research. As a consequence, these actions aim to put in practice the principles of permanent and sustainable development, in order to ensure the high level of entire environmental protection through integrated treatment of the whole process of preventing the emissions of pollutants and, where it is not entirely possible, reducing them to the greatest extent possible. The requirements of the IPPC directive are related to the activities carried out by entrepreneurs mainly in power, mineral, chemical, agriculture and food, paper, textile, tanning, production and processing of metals industries as well as in waste management (Evrard et al. 2016).

With regard to the characteristics of new environmental technologies, it should be stated that investments in new technologies are not only required by directives and legal regulations, but also by rarity of natural resources. Therefore, the environmental conditions creating and implementing new environmental technologies for companies contribute to minimizing negative external effects connected to the functioning of the company in the environment, on the one hand, yet on the other hand, they contribute to sustainable socio-economic development. In view of the above relationships, it is appropriate to present research results concerning the investments of Polish companies in new environmental technologies in the following part of this chapter. 


\section{Investments in New Environmental Technologies - Research Results}

This section describes collective results carried out over the period 2012-2015 within the framework of the GreenEvo project of the Polish Ministry of Environment and the program of European Commission - The Environmental Technology Verification (ETV). The data concerning investments in new environmental technologies of Polish companies will be analyzed. According to the research results, among the factors determining the creation of new environmental technologies among Polish companies, results of a company's own research and development and identification of market needs are most commonly mentioned. A detailed breakdown has been presented in Figure 1.

Besides the results of a company's own research and development and identification of market needs, the client also has influence on creating new technologies. On the one hand, he orders the product and, on the other hand, he makes valuable comments concerning its functionality and performance. It is worth highlighting here that in some cases it was the clients who were the inspiration for the studied companies to create new environmental technologies; however, more often, the information from the clients contributed to modernizing already existing solutions. It should also be highlighted that new environmental technologies are created thanks to effective cooperation of business and science. It is important to bear in mind that the cooperation between the business and science sectors is playing an increasingly important role in the Polish economy as well as in the market of new environmental technologies. On the one hand, entrepreneurs discover possibilities of carrying out joint projects with scientific institutions. On the other hand, the scientists learn about the specific characteristics of the market and try to meet the expectations of its participants.

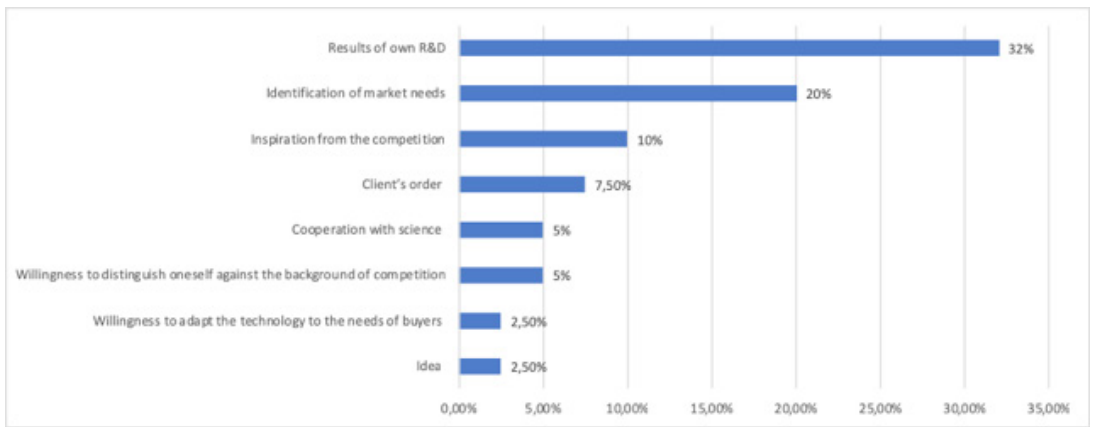

Fig. 1: Determinants of investments in new environmental technologies of Polish companies.

Source: Own study based on: Polski rynek nowych technologii Środowiskowych, Warszawa, 2013 and Environment Technology Verification pilot programme, Brussels 2016. 
Polish companies investing in new environmental technologies in $80 \%$ of cases declare their cooperation with universities and research institutes. Almost $20 \%$ explicitly acknowledge that they do not have any such cooperation. The cooperation with universities concerns various forms of collaboration. Particular forms of cooperation are displayed in Figure 2.

Among the forms of cooperation, practical student training and scientific internships occupy a unique position. Therefore, it should be assumed that it is the best way for the companies to obtain candidates for work as well as to acquire new scientific knowledge that may be commercialized.

By analyzing the subsequent results, it can be concluded that for companies creating new environmental technologies, the second-best form of cooperation with entities in the science and research sector is through science centers carrying out commissioned research concerning creating or improving technologies. In addition, $60 \%$ of companies contract projects, which are connected with improving existing technologies, to science and research sector entities. The cooperation chiefly concerns implementing particular elements of R\&D that, according to respondents, are most often connected with the lack of equipment or scientific knowledge in companies. It is also important that half of the companies contract preparation of expert opinions and analyses to universities and research centers. Their goal is a verification of technical parameters of the offered solutions in order to authenticate them on the market. Another area of cooperation between universities and companies is renting laboratories belonging to the science sector, as well as didactic activities. In this respect, the didactics is connected with conducting seminars and presentations at universities by entrepreneurs and business representatives participating in scientific conferences.

In the context of cooperation between companies creating new environmental technologies with entities of science and research sector, it is also worth

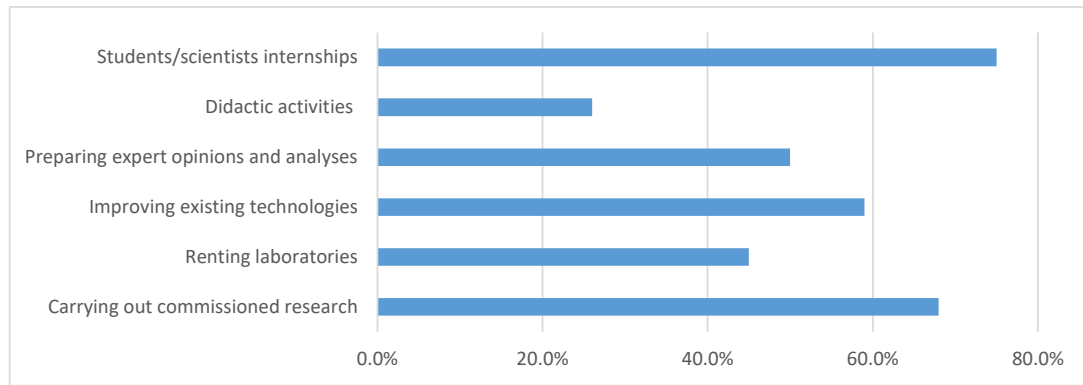

Fig. 2: Cooperation of companies creating new environmental technologies with science.

Source: Own study based on: Polski rynek nowych technologii Środowiskowych, Warszawa, 2013 and Environment Technology Verification pilot programme, Brussels 2016. 
presenting the reasons for the lack of cooperation. Diverging goals of science and business (26\%), costs of cooperation (24\%), lack of trust (22\%) and outdated/lack of research infrastructure at universities (19\%) were among the most common obstacles. While analyzing the most important obstacles, it should be noted that the divergence of particular goals may result from the fact that the science and research sector entities do not concentrate on the needs of the market as much as businesses do. It constitutes the main obstacle to undertake joint activities. Another problem is the lack of dedicated financial tools that may support the cooperation with the science sector, which in case of common (according to the entrepreneurs' declarations) overvaluation of research works constitutes a serious barrier. The lack of entrepreneurs' trust in research centers is another barrier. It is a result of entrepreneurs' concerns with possible leaks of their knowledge or universities misappropriating the rights to jointly developed solutions. The last barrier is outdated or lack of research infrastructure at universities that might meet the demand of contemporary business.

Significant supplementing of the analysis concerning the cooperation of new environmental technologies companies with science would be the result of research in collaboration with other entities in the field of implementing new environmental technologies. Figure 3 presents the detailed results.

In the vast majority of cases, the implementations are carried out in collaboration with other companies or solely by external companies. This is primarily due to the size of these organizations, the cost of dedicated services, specializing in performing specific activities, or an option of carrying out supervisory work. Taking into account the size of a company, one can observe that small and medium-sized enterprises mainly carry out independent implementation or in cooperation with external stakeholders. However, big entities usually delegate the implementation to external companies. In terms of costs of dedicated

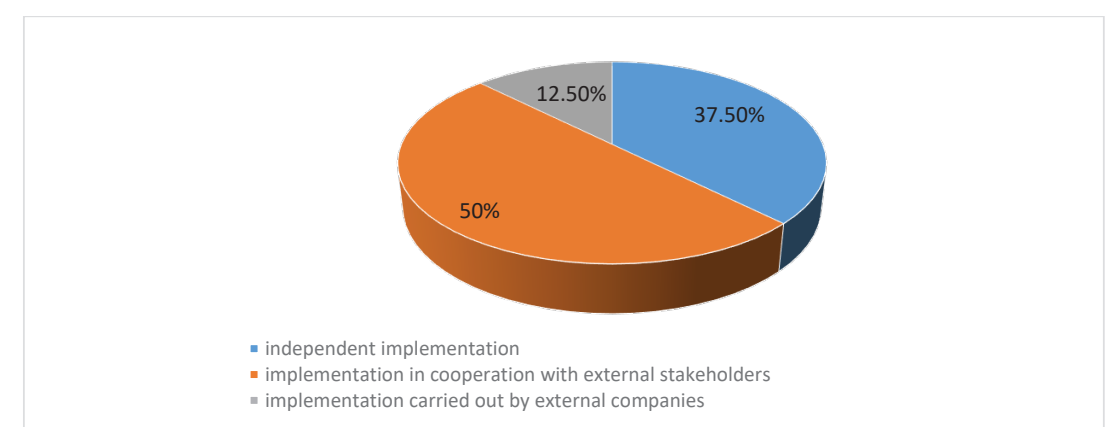

Fig. 3: Cooperation of companies creating new environmental technologies with other entities in the field of implementing new technologies.

Source: Own study based on: Polski rynek nowych technologii Środowiskowych, Warszawa, 2013 and Environment Technology Verification pilot programme, Brussels 2016. 
services and specializing in performing specific activities, the delegation of implementation of new environmental technologies or cooperation with other entities depends mostly on the size of the project and its specific nature.

Analyzing the supervisory work of companies, it may be noticed that the implementation of new environmental technologies by partners with company supervision is carried out when the basic activities are carried out by external companies and the supplier mostly executes oversight over the correctness of the work done and integrates the system in such a way that the main project assumptions may be implemented in the end. However, when the implementations are carried out in cooperation with external companies, the companies share the range of implementation activities or, in certain circumstances, the entire workmanship with other entities. This remarkably often concerns creating the finished product, creating a project or configuration of machinery and equipment by external companies.

The results connected with identifying new environmental technologies with eco-innovations are another interesting aspect of the study. Over 70\% of the surveyed entities identifies creating new environmental technologies with eco-innovations. Therefore, the entrepreneurs emphasize that the new technology is created as a result of research which frequently has all the traits of basic research. In addition, the entrepreneurs also notice that new technologies are connected with a so-called market destruction, which is reflected in introducing a new solution/product/service to the market. However, 25\% of the entrepreneurs clearly state no connection with eco-innovations, arguing that the new technology is chiefly connected with the implementation of a new combination of the factors of production, resulting in the creation of a product or service that is already on the market, in the production and service process. Only $5 \%$ of manufacturers had no opinion on this matter, emphasizing that the process of creating new environmental technologies is of no importance to them.

When assessing the importance of financial and non-financial support for a company where a new environmental technology is created, it should be stated that approximately $80 \%$ of companies create a new technology based on the resources generated from current sales. Additionally, around $10 \%$ acquire money by means of credits or bank loans, whereas 3\% obtain money from professional investors or the stock market.

In view of the fact that in the vast majority of cases, the companies creating new environmental technologies rely on their own financial resources, it is worth making a diagnosis of the size of the funding of these works (Figure 4).

The majority of studied companies $(25.82 \%)$ spend between $3 \%$ and $5 \%$ of their annual income on creating new environmental technologies. The entities whose level of funding did not exceed 3\% (21.74\% of companies) as well as those between $5 \%$ and $8 \%$ (19.78\% of companies) accounted for a substantial proportion. The companies spending over $8 \%$ on innovative activities constituted the least numerous group. 


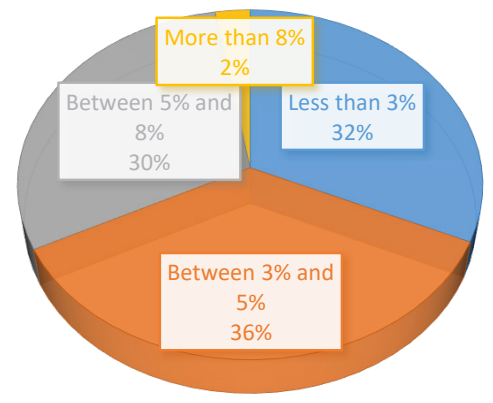

Fig. 4: The size of the funding from own financial resources of works connected with creating new environmental technologies by companies.

Source: Own study based on: Polski rynek nowych technologii Środowiskowych, Warszawa, 2013 and Environment Technology Verification pilot programme, Brussels 2016.

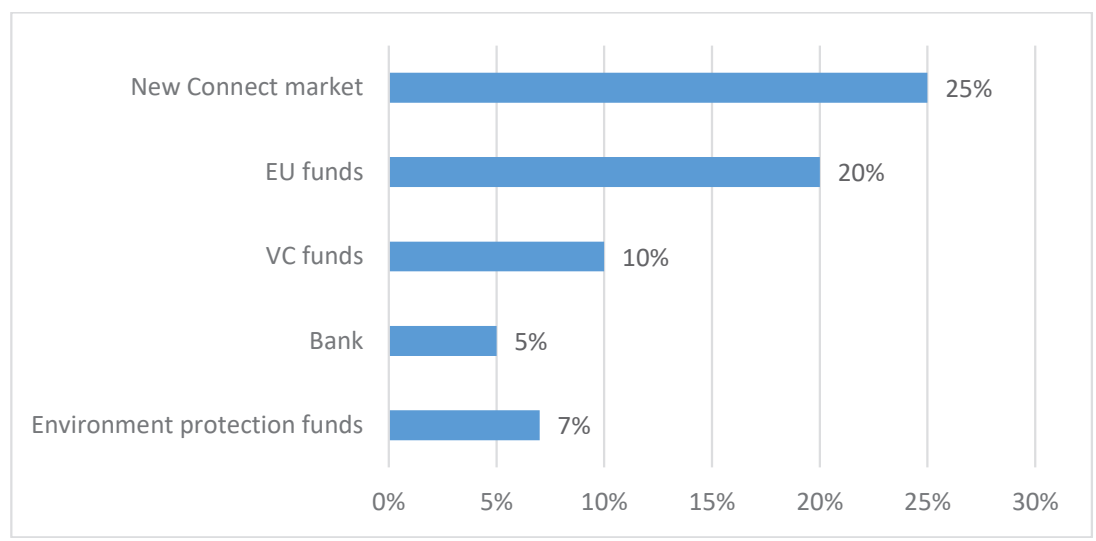

Fig. 5: Awareness with regard to obtaining financial support to create new environmental technologies.

Source: Own study based on: Polski rynek nowych technologii Środowiskowych, Warszawa, 2013 and Environment Technology Verification pilot programme, Brussels 2016.

Taking into account a very small percentage companies utilizing external capital to create new environmental technologies, it is worth making an analysis concerning respondents' awareness with regard to potential sources of financial resources from the market (Figure 5).

Among significant external sources of capital, NewConnect market is enumerated among other things. In this regard, there are a few significant reasons that encourage companies to enter the capital market. The most important 
reason is willingness to obtain capital for development. Prestige is also important, as well as benefits resulting from company transparency, including facilitating tender participation. However, among the firms that are unwilling to enter the NewConnect market, the low concern results in most cases from the lack of need for additional capital in the context of creating new environmental technology and from willingness to preserve independence in managing the company. What is more, entrepreneurs' unwillingness to enter the NewConnect market results from the feeling of low and stagnant demand for the products on the market and also from the fact that in spite of possessing modern environmental technologies, they would obtain low valuation on the stock exchange market, which could contribute to acquiring too low sums for scheduled further investments.

According to the obtained results, the companies, besides acquiring financial resources from NewConnect market, indicate EU funds or finding a strategic partner who, besides capital, would also bring additional benefits, i.e. knowledge and technology transfer from one to the other entity. The smallest number of respondents indicated obtaining funds for the development of new environmental technologies from the bank or environmental protection funds.

Taking into account the possibility of companies funding the environmental investments from EU funds, it should be stated that $75 \%$ of companies applied for such support. However, less than $20 \%$ of the respondents received funding. Among the most common sources for which the companies applied were: the Innovative Economy operational programme (50\%), the European Commission's Framework Programme (20\%) and the European Commission's LIFE+ Programme (15\%). In this respect, one should bear in mind that the use of European funds for research and development activities may be a source of competitive advantage for the companies creating new environmental technology. However, big competition can result in a low success rate for a single company.

\section{Conclusions}

Summing up, we must firmly emphasize that creating new environmental technologies is one of the main tasks of contemporary business. In this way, companies create new technological environmental solutions as a result of their own research and development activities or market needs. Another important matter is also the cooperation of companies with science centers as well as other entities in implementing new technologies. Thanks to this collaboration, not only does the transfer of know-how and technology take place, but the companies also enjoy major economies of scale, which condition their growth and market efficiency. In addition, there still exists quite substantial financing of the investments connected with creating new technologies from companies' own resources with a simultaneous dislike of financing the investment process from 
external capital resources. Therefore, on the one hand, there is a need for intensifying actions of capital - investment market entities significantly increasing the funding for enterprises of creating new environmental technologies - while simultaneously for the cooperation of these very entities with other external stakeholders who contribute to the processes of companies creating new environmental technologies.

\section{References}

Beltrán-Esteve, M, and Picazo-Tadeo, A J 2015 Assessing environmental performance trends in the transport industry: Eco-innovation or catchingup? Energy Economics, 51: 570-580.

Bocken, N M P, Farracho, M, Bosworth, R and Kemp, R 2014 The front-end of eco-innovation for eco-innovative small and medium sized companies. Journal of Engineering and Technology Management, 31: 43-57.

Bossle, M B, de Barcellos, M D, Vieira, L M and Sauvée, L 2016 The drivers for adoption of eco-innovation. Journal of Cleaner Production, 113: 861-872.

Evrard, D, Laforest, V, Villot, J and Gaucher, R 2016 Best Available Technique assessment methods: A literature review from sector to installation level. Journal of CleanerProduction, 121: 72-83.

Ghisetti, C, Marzucchi, A and Montresor, S 2015 The open eco-innovation mode. An empirical investigation of eleven European countries. Research Policy, 44(5): 1080-1093.

Loyon, L, Burton, C H, Misselbrook, T, Webb, J, Philippe, F X, Aguilar, M and Bonmati, A 2016 Best available technology for European livestock farms: Availability, effectiveness and uptake. Journal of environmental management, 166: 1-11.

Triguero, A, Moreno-Mondéjar, L,and Davia, M A 2013 Drivers of different types of eco-innovation in European SMEs. Ecological economics, 92: 25-33.

Wang, Z L 2015 Triboelectric nanogenerators as new energy technology and self-powered sensors-Principles, problems and perspectives. Faraday discussions, 176: 447-458.

Wen, Z, Meng, F, Di, J and Tan, Q 2016 Technological approaches and policy analysis of integrated water pollution prevention and control for the coalto-methanol industry based on Best Available Technology. Journal of CleanerProduction, 113: 231-240.

Zhang, W F, Dou, Z X, He, P, Ju, X T, Powlson, D, Chadwick, D and Chen, X P 2013 New technologies reduce greenhouse gas emissions from nitrogenous fertilizer in China. Proceedings of the National Academy of Sciences, 110(21): 8375-8380. 